\title{
Investigation of the role of nuclear factors associated with double-stranded RNA protein members in the pathogenesis of HTLV-2
}

\author{
Jane L Murphy, William W Hall, Noreen Sheehy* \\ From 16th International Conference on Human Retroviruses: HTLV and Related Viruses \\ Montreal, Canada. 26-30 June 2013
}

It has recently been demonstrated that HTLV-1 and HTLV-2 utilise antisense transcription to express the viral proteins, HBZ and APH-2, respectively. Studies have shown that HBZ is a key player in the pathogenesis of HTLV-1 as its temporal expression appears to be critical for the development of ATL and HAM/TSP. To date very little is known about the role of APH-2 in HTLV-2 infection. Thus, to investigate its role in the pathogenesis of HTLV-2, we recently performed yeast two hybrid screens of several cDNA libraries using APH-2 as bait. We identified a member of the Nuclear Factors Associated with double-stranded RNA (NFAR) proteins as a potential interacting protein of APH-2. The NFARs have been shown to be involved in the regulation of gene expression and most notably; host antiviral defence. Our research affords the opportunity to investigate the interaction of APH-2 and NFARs and determine how this interaction impacts on HTLV-2 lifecycle events. Our findings indicate that APH-2 and NFARs interact in vivo and in vitro. Immunofluorescence demonstrates that APH-2 and NFARs localise to the nucleus. We have also performed knockdown studies to determine the effect of NFAR proteins on HTLV-2 LTR promoter activity. Our results reveal that NFARs exert no effect on basal LTR activation, but inhibit Tax2B-mediated viral transcription. Additionally we report that in the presence of APH-2, NFARs enhance Tax2B-mediated LTR activation. Overall, this study will provide novel insights into the functional role of APH-2 and NFAR proteins in the pathogenesis of HTLV-2.

* Correspondence: noreen.sheehy@ucd.ie

Centre for Research in Infectious Diseases, School of Medicine and Medical Science, University College Dublin, Ireland
Submit your next manuscript to BioMed Central and take full advantage of:

- Convenient online submission

- No space constraints or color figure charges

- Immediate publication on acceptance

- Inclusion in PubMed, CAS, Scopus and Google Scholar

- Research which is freely available for redistribution Submit your manuscript at
www.biomedcentral.com/submit C BioMed Central
- Thorough peer review 